\title{
Research About the Efficency of Using Alternative Methods of Microbiological Food Expertise
}

Puchianu Gheorghe $^{1^{\star}}$, Babii Mihaela ${ }^{2}$, Necula Valentin ${ }^{1}$ and Enache Dorin Valter ${ }^{1}$

${ }^{1}$ Faculty of Food and Tourism, Transilvania University of Brasov, Romania

${ }^{2}$ Sanitary Veterinary and Food Safety Brasov, Romania

*Corresponding author: Puchianu Gheorghe, Faculty of Food and Tourism, Transilvania University of Brasov, Castle Street, 148, Code 500123, Brasov, Tel: 0730555793; E-mail: gpuchianu@yahoo.com

Received date: July 10, 2017; Accepted date: August 8, 2017; Published date: August 10, 2017

Copyright: $\odot 2017$ Gheorghe P, et al. This is an open-access article distributed under the terms of the Creative Commons Attribution License, which permits unrestricted use, distribution, and reproduction in any medium, provided the original author and source are credited.

\begin{abstract}
In order to verify the efficiency of the rapid diagnosis alternative methods, in the Sanitary Veterinary and Food Safety Laboratory Brasov-Romania, we have examined a total of 9952 samples, collected from various processing units.

The examinations that were performed are: the quality indicators enumeration using TEMPO equipment; food pathogens detection using the VIDAS equipment and bacterial identification using the VITEK 2 COMPACT.

It was found that $4.3 \%$ of the examined samples showed positive results, most non-compliances parameters being recorded as Total Number of Germs (8.9\%), Enterobacteriaceae (8.6\%), and Staphylococcus spp. (8.3\%) and the less at the parameters of Salmonella spp. (0.9\%) Listeria spp. (1.8\%) and E. coli $0157(0.0 \%)$.
\end{abstract}

Part of the serovarians identified by the Vitek 2 Compact method, have been additional confirmed to establish the degree of correlation, using the Kaufmann-White method.

Salmonella spp., serovars identified were: Salmonella enterica serovars: saintpaul, infantis, newport, enteritidis and taksony, and the species of Listeria spp., were: L. monocytogenes, L. ivanovii and L. innocua.

Pathogenic serovars, Salmonella enterica serovar enteritidis and Listeria monocytogenes, were confirmed as $100 \%$. In the case of non-pathogenic Salmonella spp., the correlation between the two methods was $83.3 \%$ and in the case of Listeria spp, it was $100 \%$. Infantis serovar identified by the Vitek 2 Compact method was confirmed by the Kaufmann-White method as taksony.

These values express the situation of the analysed samples, in terms of microbiological contamination and the results formed the basis for corrective measures implemented in the processing units and for the sanctions imposed on the origin lots in case, of the identification of bacterial species with toxigenic potential.

Keywords: Alternative method; Standardized method; Pathogens

\section{Introduction}

Decisions on food safety involve consideration of a wide range of concerns including the public health impact of foodborne illness, the economical importance of the agricultural sector, food industry, and the effectiveness and efficiency of interventions [1]

The presence of microorganisms is particularly important for the quality, wholesomeness and freshness of food status. Generally the microorganisms are those that reduce the nutritional value of the product, or can be edible by their pathogenic action, for the degradation and production of toxic metabolites [2-4].

Microbiological criterias are very important; they provide guidance in what concerns the acceptability of food and manufacturing processes, manipulation and distribution. For this reason they must be part of the procedures, based on HACCP principles and other measures for the hygiene control, by establishing a limit above which, a food product should be considered unacceptable and contaminated [5].

In food security, an important component of the field as a whole, is to achieve food security by the sector operators, in the self-prepared control programs elaborated in accordance with applicable laws, in wich they are obliged to survey all relevant parameters, having in view the specific activity of each unit.

In this respect, the European recent regulations, reunited in the socalled "hygiene package", aimed at preventing random food risks with the obligation to ensure the food safety circuit "from fork to plate", placing all responsibility to the producers, processors and suppliers of food resources, able to bring under qualified control the quality and food health $[4,6,7]$.

Automatization in enumeration methods, can be very useful to reduce the time needed for the preparation of the average, serial dilution, counting colonies, etc. Many improvements in this field have been made, that allow laboratories to increase the efficiency and the 
Page 2 of 6

number of samples processed such as agar preparation machines, automated dilutors, automated counting devices and spiral plate $[4,8]$.

An ideal detection system should include high specificity and sensitivity; fast response time; capability for mass production; elimination or simplification of sample preparation steps; minimal perturbation of sample; and providing continuous data analysis. Much progress has been made for the last decades, including automation and high throughput for sample processing and testing $[9,10]$.

Lately, more and more rapid tests for microbiological food expertise are being used. In this regard, we can recall the tests based on the detection of antibodies and nucleic acid that revolutionized the methodology for the detection of microbial pathogens and their toxins [9].

Many years ago, it had been predicted that traditional methods of microbiological examination will be replaced by automated, rapid methods [11]. Rapid early detection of food contamination is therefore relevant for the containment of food-borne pathogens. Conventional pathogen detection methods, such as microbiological and biochemical identification are time-consuming and laborious, while immunological or nucleic acid-based techniques require extensive sample preparation and are not amenable to miniaturization for on-site detection $[12,13]$.

However, it should be noted that the results of the rapid diagnostic methods (which can be used in accordance with the provisions of Regulation 2073/2005) should be confirmed using standardized diagnostic methodologies [14,15].

\section{Materials and Methods}

In order to check the efficiency of fast alternative diagnosis methods in the Sanitary Veterinary and Food Safety Laboratory Brasov, Romania, 9952 samples were examined, taken from different processing units from the county of Brasov [16].

The microbiological examinations used were: the enumeration of quality indicators using TEMPO equipment; the detection of food pathogens using the VIDAS equipment. For the bacterial identification we used the VITEK 2 COMPACT (Table 1).

\begin{tabular}{|l|l|l|l|l|}
\hline \multirow{2}{*}{ Analysed parameters } & \multicolumn{2}{|l|}{ Samples } & \multicolumn{2}{l|}{$\begin{array}{l}\text { Rapid diagnostic methods } \\
\text { used }\end{array}$} \\
\cline { 2 - 5 } No. & $\%$ & VIDAS & TEMPO \\
\hline Salmonella spp. & 4160 & 41.8 & $\mathrm{X}$ & \\
\hline Listeria spp. & 1138 & 11.4 & $\mathrm{X}$ & \\
\hline Staphylococus spp. & 624 & 6.3 & & $\mathrm{X}$ \\
\hline $\begin{array}{l}\text { Staphylococcal } \\
\text { enterotoxin }\end{array}$ & 52 & 0.5 & $\mathrm{X}$ & \\
\hline Campylobacter spp. & 82 & 0.8 & $\mathrm{X}$ & \\
\hline E. coli & 1056 & 10.6 & & $\mathrm{X}$ \\
\hline E. Coli O157 & 8 & 0.08 & $\mathrm{X}$ & \\
\hline Enterobacteriaceae & 864 & 8.7 & & $\mathrm{X}$ \\
\hline Total Number of Germs & 1440 & 14.5 & & $\mathrm{X}$ \\
\hline Yeast and Molds & 528 & 5.3 & & $\mathrm{X}$ \\
\hline
\end{tabular}

TOTAL

$9952 \quad 100$

Table 1: The number of samples collected and examined by rapid alternative diagnostic techniques.

\section{Tempo method}

Fully automatic method, which allows the quantitative determination of bacterial germs, based on the traditional microbiology method, namely the multiple tube method. It shows sensitivity and ease of use, allows quick results to the classic method of working (3-7 d) and saving time in preparing culture media, glassware preparing for sterilization, packaging, inoculation, reading plates, autoclaving and washing glassware (Figures $1 \mathrm{~A}$ and $\mathrm{B}$ ).

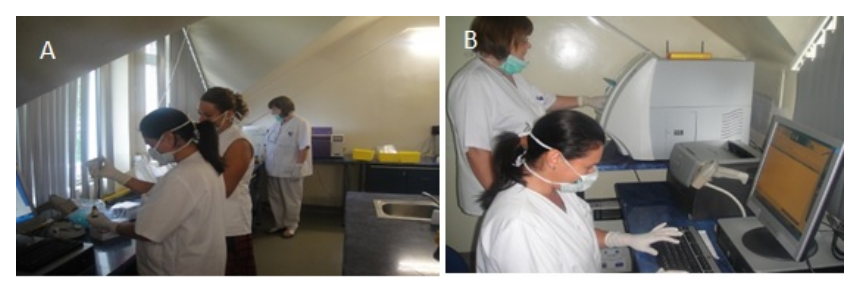

Figure 1: A. TEMPO-station preparation B. Reading station.

The TEMPO test is composed of a card with a transfer tube and a vial with a specific culture medium. The culture media is dehydrated, sterile, ready-to-use, disposable, selective TC (Total Coliforms), EC ( $E$. coli), EB (Enterobacteriaceae), STA (Staphylococcus coagulase+) LAB (Lactic acid bacteria) or -TVC non-selective (Total Number of Germs), $\mathrm{Y}+\mathrm{M}$ (Yeasts and Moulds), as identified by the bar code and the colour code (Figure 2) and TEMPO Stomacher bags (Figure 3).

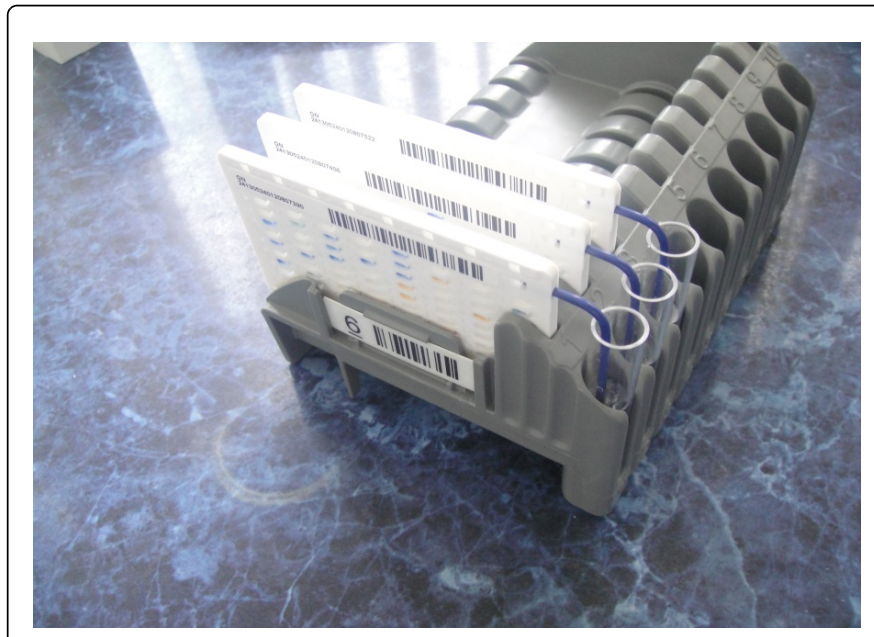

Figure 2: Card with a transfer tube and a vial. 
Page 3 of 6

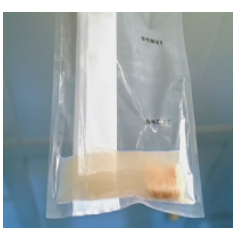

Figure 3: Type bags Stomacher.

The medium is inoculated with a dilution of the sample to be tested and it is transferred by filling tempo instrument in the tempo card. The medium is homogeneously dispersed in 48 well plates in three different volumes. The card is then hermetically sealed to avoid any risk of contamination during handling. Subsequently occurs the reading, interpretation and validation of results in a single transfer step.

\section{Examples:}

Tempo TVC tempo EC: During the incubation, the microorganisms present in the card reduces the culture medium substrate and causes the appearance of a fluorescent signal that is detected by the TEMPO reader. Depending on the number and size of positive wells, the tempo system inferred the Total Number of Germs (CCT test) or the E. coli (EC test) present in the original sample, according to the calculation, based on the most probable number method.

Tempo TC: The culture medium contains a fluorescent indicator which, when the $\mathrm{pH}$ is neutral, emits a signal detected by the tempo reader. During the incubation, the total coliforms present in the card, ferment lactose from the culture medium, resulting the decrease of $\mathrm{pH}$ and disappearance of the fluorescence signal. Depending on the number and size of positive wells, TEMPO system infers the total number of coliforms present in the original sample as calculated, based on the most probable number method.

Bacterial germs, matrices of which they can be identified and the time required for laboratory diagnosis are set out in Table 2 .

\begin{tabular}{|c|c|c|}
\hline $\begin{array}{l}\text { Bacterial germs that } \\
\text { can be identified }\end{array}$ & Matrix (examples) & The time taken (hrs) \\
\hline E. coli & $\begin{array}{l}\text { Meat, mechanically } \\
\text { separated meat, cheese } \\
\text { produced from milk } \\
\text { treated in the heat, non- } \\
\text { animal food products. }\end{array}$ & 24 \\
\hline Staphylococus spp. & $\begin{array}{l}\text { Cheese made from raw } \\
\text { milk subjected to lower } \\
\text { heat treatment then } \\
\text { pasteurization and from } \\
\text { heat-treated milk, milk } \\
\text { powder, fish products. }\end{array}$ & 24 \\
\hline Enterobacteriaceae & $\begin{array}{l}\text { Cattle carcases, sheep, } \\
\text { goats, horses, swine } \\
\text { carcases, pasteurized } \\
\text { milk and pasteurized milk } \\
\text { products, milk powder, ice } \\
\text { cream and dairy desserts, } \\
\text { dried infant formulas and } \\
\text { foods for medical } \\
\text { purposes, egg products. }\end{array}$ & C \\
\hline Total Number of Germs & $\begin{array}{l}\text { Raw milk, cattle carcase, } \\
\text { sheep, goats, swine, }\end{array}$ & 48 \\
\hline
\end{tabular}

\begin{tabular}{|l|l|l|}
\hline & $\begin{array}{l}\text { horses, poultry carcases, } \\
\text { minced and mechanically } \\
\text { separated meat. }\end{array}$ & 72 \\
\hline Yeast and Molds & Bakery & 72 \\
\hline
\end{tabular}

Table 2: Bacterial germs, matrices of which they can be identified and the time required for laboratory diagnosis.

\section{Method using the automatic analyser MiniVidas}

It is a compact high performance system, for identifying highly pathogenic microorganisms (Salmonella spp., Listeria monocytogenes, Campylobacter jejuni, E. coli O 157, Staphylococcal enterotoxin), with the immunoassay principle.

Its use allows time saving for the preparation of culture media, glassware sterilization, packaging, labelling, inoculation, reading the plates, washing the autoclave and glassware, etc. using ready for use reagents.

MiniVidas automatic analyser offers the possibility of a large number of analyses, applications, safety and ease of use, being an automatic device, standardized, robust, allowing an objective reading and delivering a quick result compared to classical working methods (Figure 4).

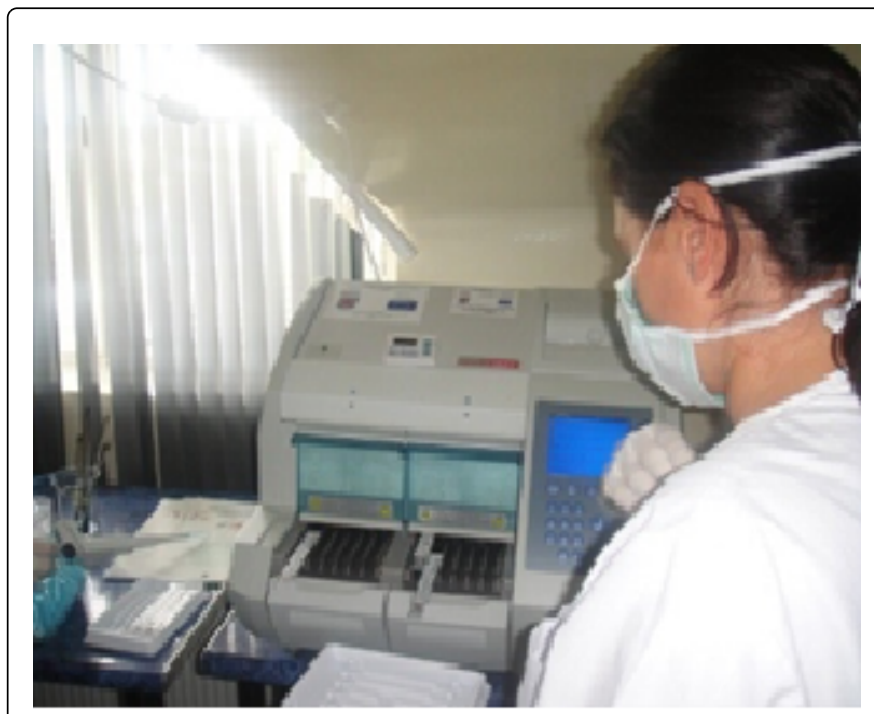

Figure 4: MiniVidas, automated analyzer.

Bacterial germs, matrices of which they can be identified and the time required for laboratory diagnosis is shown Table 3 .

\begin{tabular}{|l|l|l|}
\hline $\begin{array}{l}\text { Bacterial germs that can be } \\
\text { identified }\end{array}$ & Matrix & $\begin{array}{l}\text { The time } \\
\text { taken (hrs) }\end{array}$ \\
\hline Salmonella spp. & All food during their shelf life & 48 \\
\hline Lsteria monocytogenes & $\begin{array}{l}\text { All food before leaving from the } \\
\text { direct control of the processing } \\
\text { units, food products available } \\
\text { on the market during their shelf } \\
\text { life (meat and meat products, } \\
\text { raw material milk, cheese from } \\
\text { unpasteurized milk, }\end{array}$ \\
\hline
\end{tabular}


Citation: Gheorghe P, Mihaela B, Valentin N, Valter ED (2017) Research About the Efficency of Using Alternative Methods of Microbiological Food Expertise. Clin Microbiol 6: 292. doi:10.4172/2327-5073.1000292

Page 4 of 6

\begin{tabular}{|l|l|l|}
\hline & $\begin{array}{l}\text { confectionery and pastry } \\
\text { dishes, fish and fish products). }\end{array}$ & \\
\hline Campylobacter jejuni & $\begin{array}{l}\text { Bird carcases-in the warm } \\
\text { season. }\end{array}$ & 72 \\
\hline E. coli 157 & $\begin{array}{l}\text { Beef meat, minced meat and } \\
\text { meat products containing beef. }\end{array}$ & 72 \\
\hline Staphylococcal enterotoxin & $\begin{array}{l}\text { Cheeses made from raw milk } \\
\text { subjected to heat treatment } \\
\text { than pasteurization and low } \\
\text { heat-treated milk, milk powder, } \\
\text { fish products. }\end{array}$ & 72 \\
\hline
\end{tabular}

Table 3: Bacterial germs, matrices of which they can be identified and the time required for laboratory diagnosis.

select pathogenic and highly pathogenic micro-organisms isolated on solid media, their biochemical tests is performed extremely rapid while saving time in the results engendering.

Using it, saves materials and reagents. The used card saves all the necessary reagents for identifying and confirming and does not require any type of glass, heat sterilization, the pre-stage thermostat or other diagnostic operations.

Equipment is easy to use, with reduced labor time, intuitive software and connection to ATLAS Vet LIMS System. The method is fully automated, for diagnosis using different cards, which enables the identification of bacteria: Gram positive (GP), Gram negative (GN), anaerobic bacteria (ANC), Campylobacter spp. (NH), Corynebacterium spp. (CBC), Yeasts and Molds (YST) and Bacillus spp. (BCL), eg. Salmonella spp. (Figure 5).

\section{Vitek 2 Compact}

The equipment Vitek 2 Compact, is an automatic system for the identification and biochemical confirmation and antibiotic test, able to

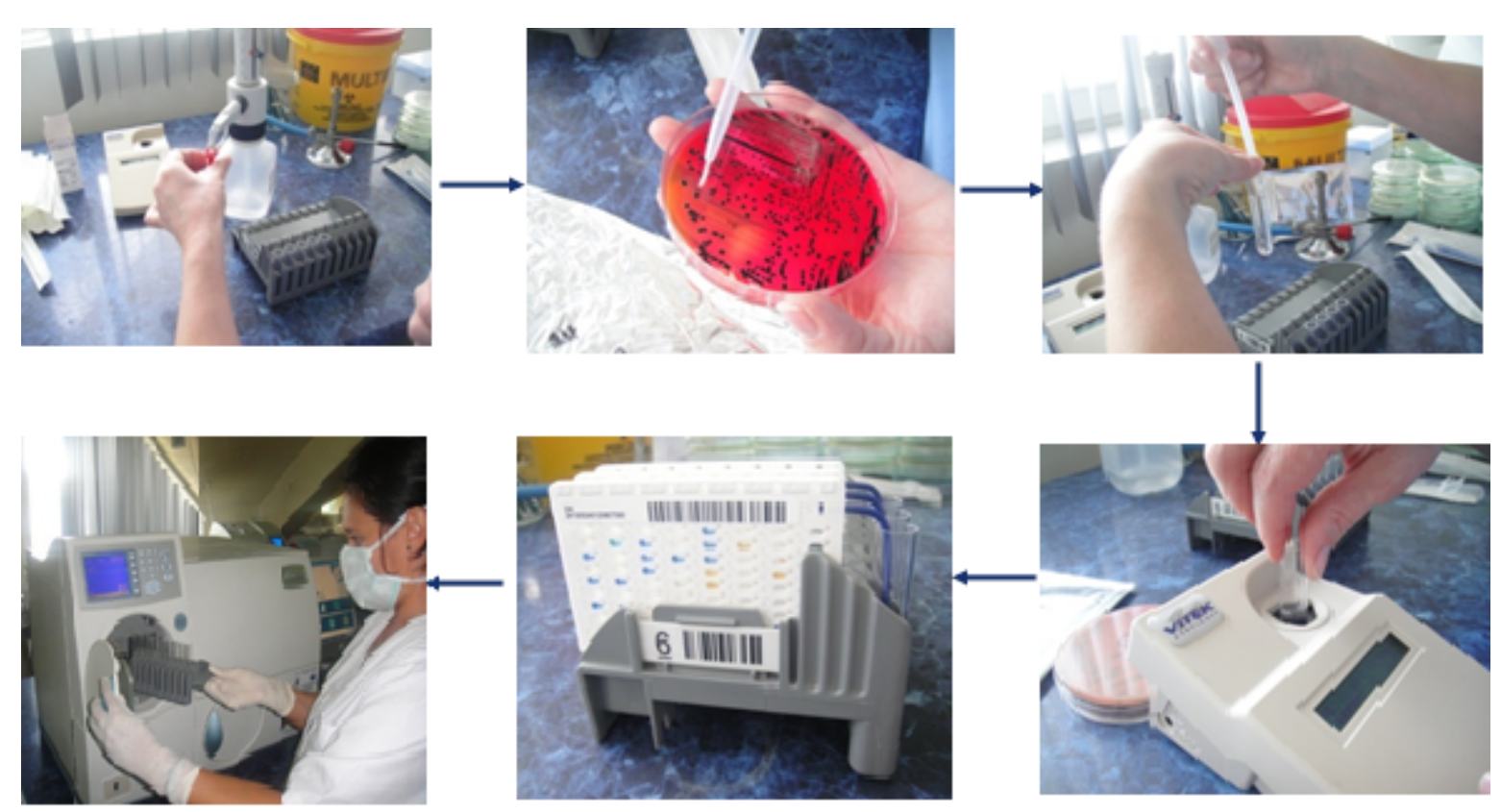

Figure 5: Steps of identification of Salmonella spp.

Bacterial germs that can be identified and the required time for laboratory diagnosis are mentioned in Table 4.

\begin{tabular}{|l|l|}
\hline $\begin{array}{l}\text { Bacterial germs that can be } \\
\text { identified }\end{array}$ & $\begin{array}{l}\text { Time needed to perform laboratory tests } \\
\text { (hrs) }\end{array}$ \\
\hline E. coli & $4-6$ \\
\hline Staphylococcus spp. & $4-6$ \\
\hline Salmonella spp. & $5-6$ \\
\hline Listeria monocytogenes & $7-8$ \\
\hline Campylobacter jejuni & $8-12$ \\
\hline E. coli A 157 & $5-6$ \\
\hline
\end{tabular}

\begin{tabular}{|l|l|}
\hline Corynebacterium spp. & $4-6$ \\
\hline Bacillus spp. & $4-6$ \\
\hline Yeasts and molds & $4-6$ \\
\hline
\end{tabular}

Table 4: Bacterial germs that can be identified and the required time for laboratory diagnosis, using Vitek 2 Compact.

\section{Results}

After analyzing the 9952 samples by rapid alternative methods, the following results is shown Table 5 . 
Page 5 of 6

\begin{tabular}{|l|l|l|l|l|l|l|}
\hline \multirow{2}{*}{$\begin{array}{l}\text { Parameters } \\
\text { analysed }\end{array}$} & \multirow{2}{*}{ Samples } & \multirow{4}{*}{$\%$} & \multicolumn{3}{l}{ D. c. results } \\
\cline { 4 - 7 } & & & Inconsistent & \multicolumn{2}{l|}{ Compliant } \\
\cline { 3 - 7 } & No. & $\%$ & No. & $\%$ \\
\hline Salmonella spp. & 4160 & 41.8 & 36 & 0.9 & 4124 & 99.1 \\
\hline Listeria spp. & 1138 & 11.4 & 21 & 1.8 & 1117 & 98.2 \\
\hline $\begin{array}{l}\text { Staphyloccocal spp. } \\
\text { Staphylococcal } \\
\text { enterotoxin }\end{array}$ & 624 & 6.3 & 52 & 8.3 & 572 & 91.7 \\
\hline Campylobacter spp. & 82 & 0.5 & 4 & 7.7 & 48 & 92.3 \\
\hline E. coli & 1056 & 10.6 & 64 & 6.1 & 992 & 93.9 \\
\hline E. coli O157 & 8 & 0.08 & - & - & 8 & 100 \\
\hline Enterobacteriaceae & 864 & 8.7 & 74 & 8.6 & 790 & 91.4 \\
\hline $\begin{array}{l}\text { Total Number } \\
\text { Germs }\end{array}$ & 1440 & 14.5 & 128 & 8.9 & 1312 & 91.1 \\
\hline Yeast and Molds & 528 & 5.3 & 38 & 7.2 & 490 & 92.8 \\
\hline TOTAL & 9952 & 100 & 420 & 4.3 & 9532 & 96.7 \\
\hline
\end{tabular}

Table 5: The results of the examination samples using fast alternative techniques of diagnosis.

In all cases, the interpretation was done in accordance with regulation 2073/2005 in which the microbiological safety criterias are provided, which defines the acceptable character of the products, and also safety microbiological criteria of food products that should establish a line above which a food product must be considered unacceptably contaminated.

It was found that $4.3 \%$ of the examined samples showed positive results, most of the non-concordances recorded for Total Number of Germs (8.9\%), Enterobacteriaceae (8.6\%), and Staphylococcus spp. (8.3\%) and the less in the case of E. coli O157, Salmonella spp. (0.9\%) and Listeria spp. (1.8\%).

These values express the situation of the analysed samples, under the aspect of microbiological contamination, and the results has constituted the basis for corrective measures implemented in the processing units and for the sanctions imposed on the origin lots in case of bacterial species with toxigenic potential were identified. The ultimate were put under distraint until confirmation or refutation of the results obtained by reference tests.

The reference methods used to confirm the positivity of cases obtained after use fast alternative techniques of diagnosis were as follows (Table 6).

\begin{tabular}{|l|l|}
\hline Parameters analysed & Reference test used \\
\hline Salmonella spp. & ISO $6579 / 2003 \mathrm{AC} / 2006$ \\
\hline Listeria spp. & ISO $11,290-1,2$ \\
\hline Staphylococcal spp. & ISO $6888-1.2$ \\
\hline Staphylococcal enterotoxin & $\begin{array}{l}\text { European screening method of the EU- } \\
\text { RL }\end{array}$ \\
\hline Campylobacter spp. & ISO 16649 \\
\hline
\end{tabular}

\begin{tabular}{|l|l|}
\hline E. coli & ISO $16649-1.2$ \\
\hline E. coli O157 & ISO $16649-1.2$ \\
\hline Enterobacteriaceae & ISO $21,528-1.2$ \\
\hline Total Number of Germs & ISO $4833 / 2003$ \\
\hline Yeast and Molds & ISO $21527-1$ \\
\hline
\end{tabular}

Table 6: The reference methods used to confirm positivity of cases.

Using only the standardized methods in the food microbiological expertise, has some disadvantages: they are laborious; requires a longer working time (3-6 days delay of finished product delivery and providing a delayed data response from the monitoring program of hygiene); a greater amount of consumables and many suppliers; the results can be subjective (many false negative and false positive), they depend on the experience and expertise of persons involved in analytical process and high uncertainty of measurement.

They remain, however, very important, being the ones on which we base to report the results of other diagnosis methods used in microbiology.

The concordance of the results was $100 \%$, which demonstrates that the use of fast alternative methods can be successfully used, generating results equivalent to those obtained by using the reference method (Table 7).

\begin{tabular}{|c|c|c|c|}
\hline \multirow[t]{2}{*}{ Parameters analysed } & \multirow{2}{*}{$\begin{array}{l}\text { Non-concordant } \\
\text { samples at rapid } \\
\text { alternative methods }\end{array}$} & \multicolumn{2}{|c|}{$\begin{array}{l}\text { Samples not in } \\
\text { concordance with the } \\
\text { reference tests }\end{array}$} \\
\hline & & No. & $\%$ \\
\hline Salmonella spp. & 36 & 36 & 100 \\
\hline Listeria spp. & 21 & 21 & 100 \\
\hline Staphylococcus spp. & 52 & 52 & 100 \\
\hline Staphylococcal enterotoxin & 4 & 4 & 100 \\
\hline Campylobacter spp. & 3 & 3 & 100 \\
\hline E. coli & 64 & 64 & 100 \\
\hline E. Coli 0157 & - & - & 100 \\
\hline Enterobacteriaceae & 74 & 74 & 100 \\
\hline Total Number of Germs & 128 & 128 & 100 \\
\hline Yeast and Molds & 38 & 38 & 100 \\
\hline TOTAL & 420 & 420 & 100 \\
\hline
\end{tabular}

Table 7: Concordance results obtained from the use of the reference methods.

Part of the serotypes identified by the Vitek 2 Compact method were analyzed at the Institute of Hygiene and Veterinary Public Health Bucharest Romania, using the Kaufmann-White method. Thus, in the case of Salmonella spp, a number of 12 serovars were analyzed, representing 33\%. The isolated serovars were: Salmonella enterica serovars: saintpaul, infantis, newport, enteritidis and taksony (Table 8). 


\begin{tabular}{|l|l|l|l|l|l|l|l|l|l|l|}
\hline \multirow{2}{*}{ Method used } & \multicolumn{9}{|l|}{ Serovars identified } \\
\cline { 2 - 12 } & \multicolumn{2}{|l|}{ Salmonella enterica from which serovar } \\
\cline { 2 - 11 } & enteritidi & \multicolumn{2}{l|}{ taksony } & \multicolumn{2}{l|}{ infantis } & \multicolumn{2}{l|}{ newport } & \multicolumn{2}{l|}{ saintpaul } \\
\cline { 2 - 11 } & No. & $\%$ & No. & $\%$ & No. & $\%$ & No. & $\%$ & No. & $\%$ \\
\hline $\begin{array}{l}\text { Kaufmann-White } \\
\text { method }\end{array}$ & 2 & 16.7 & 2 & 16.7 & 3 & 25.0 & 3 & 25.0 & 2 & 16.7 \\
\hline $\begin{array}{l}\text { Vitek 2 Compact } \\
\text { method }\end{array}$ & 2 & 16.7 & 1 & 8.3 & 4 & 33.3 & 3 & 25.0 & 2 & 16.7 \\
\hline Correspondence & 100 & & 50 & & 75 & & 100 & & 100 \\
\hline
\end{tabular}

Table 8: Salmonella spp. serovars, identified.

A correlation of $83.3 \%$ was found and it was being noted that the infant serotype identified by the Vitek 2 Compact method was confirmed by the Kaufmann-White method as taksony. It was observed that seovar enteritidis is the only one with pathogenic potential of the isolates, being confirmed in $100 \%$. The other identified serovars have a low degree of pathogenicity, assisting thermal processing of food which does not constitute a risk of generating food poisoning to consumers.

In the case of Listeria spp., 7 species were analyzed, representing $33 \%$. The isolated species were: $L$. monocytogenes, $L$. ivanovii and $L$. innocua (Table 9).

\begin{tabular}{|l|l|l|l|l|l|l|}
\hline \multirow{2}{*}{ The method used } & \multicolumn{2}{|l|}{ L. monocytogenes } & \multicolumn{2}{l|}{ L. inanovi } & \multicolumn{2}{l|}{ L. innocua } \\
\cline { 2 - 7 } & No. & $\%$ & No. & $\%$ & No. & $\%$ \\
\hline $\begin{array}{l}\text { Kaufmann-White } \\
\text { method }\end{array}$ & 2 & 28.6 & 4 & 57.1 & 1 & 14.3 \\
\hline $\begin{array}{l}\text { Vitek 2 Compact } \\
\text { method }\end{array}$ & 2 & 28.6 & 4 & 57.1 & 1 & 14.3 \\
\hline Correspondence & & $\mathbf{1 0 0}$ & & $\mathbf{1 0 0}$ & & $\mathbf{1 0 0}$ \\
\hline
\end{tabular}

Table 9: Species of Listeria spp., isolated and confirmed.

There is a $100 \%$ correlation between the two used methods.

\section{Conclusions}

During food microbiological expertise using alternative methods, non-concorcondance have been identified in $4.3 \%$ of the examined samples. Most non-concordances were recorded for total number of germs (8.9\%), Enterobacteriaceae (8.6\%) and Staphylococcus spp. $(8.3 \%)$ and the lowest in the case of E. coli O157 (0\%), Salmonella spp. (0.9\%) and Listeria spp. (1.8\%).

The results formed the basis for corrective measures implemented in processing units and sanctions imposed on the lots of origin for the identification of bacterial species with toxigenic potential. They were sequestered until results confirmation or refutations were obtained by the reference tests.

Part of the serotypes identified by the Vitek 2 Compact method (Salmonella spp. and Listeria spp.), were confirmed by the Kaufmann-
White method in $83.3 \%$, in the case of Salmonella spp., and $100 \%$ in the case of Listeria spp. Pathogenic serovars of Salmonella spp. and Listeria spp. with a risk of generating food poisoning have been confirmed in $100 \%$.

We recommend that rapid diagnosis methods can be used in particular, to carry out the self-monitoring program of the units, taking into account the short time necessary to generate analysis report.

\section{References}

1. Havelaar AH, Bräunig J, Christiansen K, Cornu M, Hald T, et al. (2007) Towards an Integrated Approach in Supporting Microbiological Food Safety Decisions, Journal compilation, Blackwell Verlag, Berlin. Zoonoses Public Health 54: 103-117.

2. Puchianu G, Bogdan AT, Andronie V, Toba GF, Lăcrimioara P (2011) Updates of the Veterinary Medicine Role in the Expertise of Food Safety and Security in the World Professional Year. Romanian Acad Sci Publishing House 2: 409-420.

3. Puchianu G, Necula V, Enache DV, Şerban D (2014) Research on the efficiency of alternative methods in microbiological expertise of food products. International Conference on New Research in Food and Tourism, Bioatlas, Brasov 15th -17th May 2014.

4. Jasson V, Jacxsens L, Luning P, Rajkovic A, Uyttendaele M (2010) Alternative microbial methods: An overview and selection criteria. Food Microbiol 27: 710-730.

5. Enache D, Serban D, Puchianu G, Necula V (2014) Ensuring the protection of critical infrastructure in the food industry through the implementation of the food - defense" - IDESPERAS2L182. The International Conference - Economic Scientific Research - Theoretical, Empirical and Practical Approaches, ESPERA.

6. Raugel PJ (1999) Rapid Food Analysis and Hygiene Monitoring. Kits, Instruments and Systems (1st Ed). Springer, pp. 53 -85.

7. Roberts TA (1997) Maximizing the Usefulness of Food Microbiology Research. Emerg Infect Dis 3: 523-528.

8. Arcot J, Sherestha A (2005) Folate: methods of analysis in foods. T Food Sci Technol 1-14.

9. Beilei G, Meng J (2009) Advanced Technologies for Pathogen and Toxin Detection in Foods: Current Applications and Future Directions. SLAS TECHNOLOGY: Translating Life Sciences Innovation. 14: 235-241.

10. Juste A, Thomma BPHJ, Lievens B (2009) Recent advances in molecular techniques to study microbial communities in food-associated matrices and processes. Food Microbiol 25: 745-761.

11. Vasavada PC (1993) Rapid methods and automation in food microbiology: beyond delphi forecast. J Rapid Methods Autom Microbiol 2: 1-7.

12. Singh A, Poshtiban S, Evoy S (2013) Recent Advances in Bacteriophage Based Biosensors for Food-Borne Pathogen Detection. Sensors (Basel) 13: 1763-1786.

13. Jacxsens L, Luning PA, Marcelis WJ, Van Boekel T, Rovira J, et al. (2011) Tools for the performance assessment and improvement of food safety management systems. T Food Sci Technol 22: S80-S89.

14. Council Regulation (EC) 2073/2005 regarding microbiological criteria for foodstuffs published in the Official Journal of the European Union.

15. Council Regulation (EC) Commission Regulation (EC) No 1441/2007 of 5 December 2007 amending Regulation (EC) 2073/2005 on microbiological criteria for food.

16. Bacterial Nomenclature up - to - date (Approved lists, validation lists) (2012) Compiled by Leibniz Institute DSMZ - Deutsche Sammlung von und Mikroornismen Zellkulturen GmbH, Braunschweig, Germany. 